\title{
FIKIH MANGROVE: FORMULASI FIKIH LINGKUNGAN PESISIR PERSPEKTIF EKO-SYARIAH
}

\author{
Moh. Mufid \\ Universitas Islam Negeri Sunan Ampel Surabaya | Jl. A. Yani I 17 Surabaya \\ moephid@yahoo.com.sg
}

\begin{abstract}
This article is a study of mangrove management in eco-sharia perspective. Conservation efforts in the coastal areas must be constructed based on religious values so that it is expected to create a collective attitude of environmental awareness among coastal communities. Eco-sharia as an approach can provide a new paradigm related to the preservation of the coastal environment with anthropocosmic insights. The concept of eco-ecology and ecosystem can also provide a comprehensive understanding in the effort to support the existence of coastal environment jurisprudence. Normatively, the perspective of Islamic jurisprudence on mangroves preservation can be built through an in-depth understanding of Islamic recommendations in rehabilitating mangrove habitats in coastal area; Procedure of mangrove land conversion based on consideration of principle of benefit; Thus, it is urged that local governments to issue regulations to manage mangrove preservation in a sustainable manner. Keywords: Islamic Jurisprudence, Mangrove, Coastal Environment
\end{abstract}

Abstrak: Artikel ini merupakan kajian pengelolaan mangrove dalam perspektif eko-syariah. Upaya pelestarian di wilayah pesisir harus dikonstruksi berbasis nilai-nilai religius sehingga diharapkan mampu melahirkan sikap kesadaran lingkungan secara kolektif di kalangan masyarakat pesisir. Eko-syariah sebagai suatu pendekatan dapat memberikan paradigma baru terkait pelestarian lingkungan pesisir dengan wawasan antropokosmis. Konsep ekoteologi dan ekosofi juga dapat memberikan pemahaman yang komprehensif dalam upaya mendukung eksistensi fikih lingkungan pesisir. Secara normatif, fikih mangrove dapat dibangun melalui pemahaman secara mendalam tentang anjuran Islam dalam merehabilitasi habitat mangrove di pesisir; prosedur alih fungsi lahan mangrove berdasarkan pertimbangan asas 
manfaat-mafsadat; keniscayaan pemerintah daerah menerbitkan regulasi untuk mengatur pengelolaan mangrove secara berkelanjutan.

Kata Kunci: Fikih, mangrove, lingkungan, pesisir, eko-syariah.

\section{Pendahuluan}

Hutan mangrove ${ }^{1}$ merupakan salah satu kekayaan sumberdaya pesisir yang dapat menunjang perekonomian masyarakat di wilayah pesisir. Secara ekologis, hutan mangrove selain sebagai tempat berkembangnya habitat biota laut, juga merupakan tempat pemijahan bagi ikan. Selain itu, mangrove juga dapat berfungsi sebagai wahana wisata sekaligus mampu menjadi pelindung dari berbagai ancaman sedimentasi, abrasi, pencegahan intrusi air laut dan lainnya.

Ironisnya, hutan mangrove yang memiliki fungsi strategis tersebut telah banyak mengalami kerusakan yang akut. Hal ini terbukti, praktik pengalihfungsian hutan mangrove menjadi permukiman, lahan tambak, industri wisata dan lainnya menjadi problem baru dan tantangan pengelolaan sumberdaya mangrove di wilayah pesisir. Fakta empiris terkait degradasi hutan mangrove akibat penebangan liar, pengalihfungsian lahan tambak dan permukiman justru dapat mengancam wilayah pesisir dari bahaya yang disebut environmental disasters, malapetaka lingkungan bagi masyarakat pesisir.

Dewasa ini, kondisi kelestarian hayati (biota) laut di Indonesia menghadapi ancaman serius. Bahkan, sebagian di antaranya telah mendekati kepunahan akibat pencemaran dan perusakan di wilayah pesisir. Berbagai upaya pencegahan telah dilakukan, baik oleh masyarakat, pemerintah maupun lembaga-lembaga internasional, namun tetap tidak mampu mencegah degradasi

\footnotetext{
I Term mangrove merupakan kombinasi antara bahasa Portugis "manggue" dan bahasa Inggris "grove". Dalam bahasa Inggris kata "mangrove" digunakan baik untuk komunitas tumbuhan yang tumbuh di daerah jangkauan pasang-surut maupun untuk individu-individu spesies tumbuhan yang menyusun komunitas tersebut, sementara dalam bahasa Portugis kata mangrove digunakan untuk menyatakan individu spesies tumbuhan, sedangkan kata manggal untuk menyatakan komunitas tumbuhan. Ridwan Tohopi, Konservasi Pesisir dalam Perspektif Studi Islam, (Yogyakarta: Pustaka Pelajar, 20|4), 475.
} 
kualitas lingkungan perairan laut. Menggalakkan kegiatan konservasi lingkungan pesisir merupakan salah satu solusi alternatif dalam mengatasi krisis lingkungan yang mengancam ekosistem laut tersebut. ${ }^{2}$

Secara substantif, konservasi wilayah pesisir adalah upaya perlindungan, pelestarian dan pemanfaatan serta ekosistemnya untuk menjamin keberadaan dan kesinambungan sumberdaya laut dan pantai dengan tetap memelihara dan meningkatkan kualitas nilai dan keanekaragaman hayati. Hal tersebut dilakukan karena sumberdaya pesisir, baik flora maupun fauna, dan ekosistemnya memiliki kegunaan dan nilai ekologis, ekonomis dan sosiologis yang sangat penting. ${ }^{3}$

Sebagai agama yang rahmah li al-âlamîn, Islam telah memberikan tuntunan dalam berinteraksi dengan lingkungannya, termasuk lingkungan laut dan pantai. Konsep ri'âyah al-bî̀ ah yang dikembangkan para cendikiawan muslim merupakan bagian integral dari ajaran Islam. Doktrin ini harus dapat diaplikasikan dalam kehidupan sosial umat muslim, baik secara kolektif maupun individu.

Oleh karena itu, dalam konteks inilah, menjaga ekosistem pesisir menjadi sesuatu yang niscaya. Di sini letak relevansi kajian teologis-normatif-sosiologis yang menjadi pijakan dalam upaya pemeliharan dan pengelolaan potensi sumberdaya di wilayah pesisir. Dengan demikian, gagasan fikih konservasi lingkungan pesisir pantai ini yang dipahami sebagai seperangkat aturan tentang perilaku ekologis manusia yang ditetapkan oleh ulama berkompenten berdasarkan dalil yang terperinci untuk tujuan kemaslahatan kehidupan yang bernuansa ekologis menjadi sangat urgen bagi kehidupan. ${ }^{4}$

\footnotetext{
2 Badan Pusat Statistik, Statistik Lingkungan Hidup Indonesia 2014, (Jakarta: Sub Direktorat Statistik Lingkungan Hidup, t.t.), 46.

${ }^{3}$ Ridwan Tohopi, Konservasi Pesisir dalam Perspektif Studi Islam, (Yogyakarta: Pustaka Pelajar, 20 I 4), 213.

${ }^{4}$ Dari uraian di atas, minimal ada empat hal yang perlu digarisbawahi secara opeasionalnya: pertama, seperangkat aturan perilaku yang bermakna bahwa aturan-aturan yang dirumuskan mengatur
} 
Di lain pihak, secara teoretis, terminologi eko-syariah terdiri atas "oikos" yang berarti rumah tangga dan syariah yang berarti ajaran Islam. Secara istilah, eko-syariah dapat difahami sebagai nilai-nilai ajaran Islam yang berpihak terhadap lingkungan hidup. Istilah ini ingin menegaskan bahwa ajaran Islam telah meletakkan pondasi nilai-nilai dasar dalam kerangka membangun kehidupan yang ramah lingkungan. Nilai-nilai dasar itu dapat digali dan sumber utama ajaran Islam, al-Quran dan hadis. Eko-syariah dapat menjadi pintu masuk bagi usaha-usaha konservasi lingkungan pesisir pantai berbasis nilai ajaran Islam yang bukan hanya untuk memperbaiki kualitas perlindungan lingkungan di Negara-negara Muslim, tetapi juga dapat menopang gerakan global dalam masalah pembangunan berkelanjutan.

Bertolak dari sini, sumberdaya wilayah pesisir merupakan aset yang strategis untuk dikembangkan dengan basis kegiatan ekonomi pada pemanfaatan sumberdaya pesisir dan jasa-jasa kelautan dengan memperhatikan aspek ekonomi-ekologis. Untuk itu, tulisan ini merupakan langkah antisipatif dengan mencari formulasi paradigma baru melalui format kajian eko-syariah dalam

hubungan perilaku manusia dalam interaksinya dengan alam. Rumusan aturan perilaku tersebut akan diwadahi dengan hukum-hukum fikih dalam lima wadah: al-wujûb, al-nadb, al-ibâhah, al-karâhah, dan al-hurmah. Dengan demikian, seperangkat interaksi tersebut mengacu pada status hukum perbuatan mukallaf dalam interaksinya dengan lingkungan hidup. Kedua, maksud dari kalimat "yang ditetapkan oleh ulama yang berkompeten" adalah bahwa perumusan fikih lingkungan harus dilakukan oleh ulama yang mengerti tentang lingkungan hidup dan menguasai sumber-sumber normatif (al-Qur'an, hadis, dan ijtihad-ijtihad ulama) tentang aturan fikih lingkungan. Dengan demikian, mujtahid lingkungan harus memiliki pengetahuan ideal normatif dan pengetahuan tentang fakta-fakta empirik lingkungan hidup. Oleh karena itu, perumusan fikih lingkungan "niscaya" melibatkan pengetahuan tentang ekologi. Ketiga, yang dimaksud dengan "berdasarkan dalil yang terperinci" adalah bahwa penetapan hukum fikih lingkungan harus mengacu kepada dalil. Dalil, dalam hal ini, tidak hanya dipahami secara tekstual dalam arti nash yang shârih, tetapi mencakup dalil yang diekstrak atau digeneralisasi dari maksud syariat. Keempat, maksud dari kalimat "untuk tujuan mencapai kemaslahatan kahidupan yang bernuansa ekologis" adalah sesuatu yang ingin dituju oleh fikih lingkungan, yaitu kehidupan semua makhluk Tuhan. Hal ini menggambarkan aksiologi fikih lingkungan yang akan mengatur agar semua spesies makhluk Tuhan dapat hidup dalam space alam yang wajar sehingga akan memberikan daya dukung optimum bagi kehidupan bersama yang berprikemakhlukan, rahmat li al-âlamîn. Mujiyono Abdillah, Fikih Lingkungan, (Yogyakarta: Unit Penerbitan dan Percetakan YKPN, 2005), 55-57; Sukarni, Fikih Lingkungan Hidup, (Banjarmasin: Antasari Press, 201 I), 9. 
pelestarian hutan mangrove yang diharapkan dapat mengintegrasikan kepentingan ekonomi-ekologi dalam pemanfataan wilayah pesisir secara berkelanjutan dan berkeseimbangan.

\section{Eko-Syariah: Pendekatan Normatif-Religius}

Eko-syariah sebagai suatu pendekatan, sejatinya, bukan suatu hal baru. Selain eko-syariah dikaitkan dengan nilai-nilai religius Islam secara normatif dalam menjaga lingkungan. Konsep ini juga akan dikaitkan dengan konsep eko-teologi dan eko-sofi. Kedua konsep tersebut, saat ini menjadi bagian yang integral dalam kajian pelestarian lingkungan.

Eko-teologi ini menjadi relevan dalam kajian lingkungan, karena dalam agama Islam, tauhid (teologi) merupakan basis atau kerangka dasar bagi keseluruhan pandangan dan worldview-nya. ${ }^{5}$ Tauhid adalah poros yang di sekelilingnya semua ajaran Islam bergerak dan berputar. Tauhid seperti khazanah yang dipadatkan, yang dipermukaannya tampak sederhana, namun apabila dibentangkan dan dibeberkan akan meliputi seluruh ajaran Islam. ${ }^{6}$ Hal senada diungkapkan oleh Nasr. Menurutnya, tauhid adalah jantungnya Islam (the heart of Islamic life). Oleh karenanya, hidup yang bermanfaat adalah hidup yang mampu merealisasikan makna prinsip tauhid ke dalam realitas hidup, yaitu meraih dan menyatukan berbagai keragaman (multiplicity) dan bingkai kesatuan (unity). ${ }^{7}$

Konsep tauhid pada awalnya berarti menegaskan keesaan Allah swt. Dalam perkembangannya konsep ini digunakan untuk konsep-konsep sosial, budaya dan akhirnya lingkungan hidup. Nilai tauhid ini tidak an-sich membahas keimanan dalam hati, tetapi juga harus menjadi spirit bagi tindakan atau perilakunya, baik yang

\footnotetext{
${ }^{5}$ Murtadha Mutahhari, Fundamentals of Islamic Thought, (Berkeley: Mizan Press, 1985).

${ }^{6}$ Muhammad Taqi Misbah Yazdi, At-Tauhid or Monotheism, As in The Ideological and The Value System of Islam, (Iran: Islamic Propagation Organization, t.th.), I5.

7 Sayyed Hossein Nasr, The Heart of Islam; Enduring Values for Hummanity, (New York: Harper Sanfransisco, 2002), 6.
} 
berhubungan dengan Tuhan, hubungan dengan sesama dan hubungan dengan lingkungannya. Hal ini menunjukkan bahwa manusia sebagai makhluk Tuhan sekaligus sebagai hamba Tuhan harus senantiasa tunduk dan patuh kepada aturan-aturan yang ditetapkan Tuhan. Manusia bertanggungjawab kepada-Nya atas semua tindakan yang dilakukannya. Ini mengindikasikan pula bahwa tauhid merupakan salah satu sumber nilai dalam etika dalam Islam.

Tauhid dalam Islam dijadikan sumber doktrin teologi ekologi. Semua alam semesta baik yang tampak maupun tidak adalah merupakan tanda-tanda (ayat) bagi eksistensi Allah. Segala sesuatu merupakan menifestasi Allah dan semuanya berasal dari-Nya. ${ }^{8}$ Konsep ini, menurut Nasr terlihat dalam konsep ihsân yang merupakan jantung atau hati dari Islam. ${ }^{9}$ Ihsân menimbulkan kesadaran bagi setiap manusia akan kehadiran Tuhan dalam setiap gerak dan langkahnya dalam menjalin relasi dengan alam dan makhluk lainnya.

Oleh karena itu, tauhid merupakan landasan dan acuan bagi setiap perbuatan manusia, baik perbuatan lahir dan batin termasuk dalam berfikir dan bertindak. Bagi seorang muslim, tauhid harus masuk menembus ke dalam seluruh aspek kehidupannya dan menjadi pandangan hidupnya. ${ }^{10}$ Dengan kata lain, tauhid

\footnotetext{
8 Ibn Arabi mengatakan bahwa alam ini tidak lain adalah menifestasi-manifestasi (tajalliyyât) Allah, atau lebih tepatnya manifestasi sifat-sifat, nama-nama dan af al Allah. Pada dirinya, alam tidak memiliki realitas, Tuhanlah yang memberi realitas tersebut kepada alam, oleh sebab itu, Tuhan adalah alHaqq (realitas sejati). Pandangan sufi ini juga senada dengan pandangan filsuf parepatetik, khususnya Ibn Sina yang mengatakan bahwa alam pada dirinya adalah mumkin al-wujud (sebuah potensial), jadi alam hanyalah sebuah potensi bukan aktualitas, karena itu belum memiliki realitas. Untuk dapat aktual alam membutuhkan (al-faqir dalam istilah Suhrawardi) Tuhan al-Ghaniy untuk mengaktualkan potensinya.

9 Seyyed Hossein Nasr, The Heart of Islam; Enduring Values for Hummanity, (New York: Harper Sanfransisco, 2002), 3/4.

${ }^{10}$ Dalam pandangan Fazlun Khalid, tauhid juga merupakan simbul kesatuan bagi seluruh ciptaan Allah (simboloc of the unity of creation) mulai dari tingkatkatan terkecil seperti bagian mineral, tumbuhan, hewan, bintang, manusia dan alam kosmos lainnya. Konsep ini menunjukkan kesatupaduan seluruh alam dan isinya yang terangkai dalam bingkai (frame) asal dan sumber yang sama serta tujuan yang sama. Fazlun Khalid, "Islam and Environment", in Timmerman P. (ed) Encyclopedia of Global Environment Change, (Chichester: John Wiley \& Sons Ltd, 2002), 337.
} 
merupakan sumber etika pribadi dan kelompok (masyarakat), etika sosial, ekonomi, dan politik, termasuk etika dalam pengelolaan sumberdaya alam dan lingkungan, pengembangan sains dan teknologi. ${ }^{11}$

Dalam kontek inilah, upaya pelestarian dan konservasi lingkungan pesisir merupakan salah satu bentuk keimanan seseorang terhadap Allah sebagai Pencipta alam semesta. Sebaliknya, tindakan destruktif dan eksploitatif yang dapat merusak lingkungan pesisir bertentangan dengan nilai-nilai tauhid. Sikap semacam ini, menurut Toshihiko Izutsu sama dengan sikap to be unthankful (tidak bersyukur). ${ }^{12}$ Manusia yang lupa mensyukuri, memelihara dan justru menyalahgunakan serta melanggar aturan Allah swt orang itu dikatakan kufur nikmat yang akhirnya menyebabkan hilangnya nikmat tersebut. Dengan demikian, sikap kufur dalam konteks lingkungan berarti suatu sikap yang abai (ignorant), tidak bertanggung jawab, dan semena-mena terhadap lingkungan pesisir.

Di lain pihak, konsep eko-sofi merupakan mengintegrasikan perspektif tasawuf ke dalam kajian masalah konservasi lingkungan. Tasawuf secara keseluruhan adalah ajaran tentang akhlak dan etika, baik terhadap Allah sebagai pencipta kosmos, maupun etika terhadap manusia dan alam semesta. Tradisi ajaran tasawuf yang reflektif diyakini mampu mendorong untuk lebih arif dan bijaksana dalam berinteraksi dengan alam sekitar.

Eko-sofi merupakan filsafat tentang keselarasan atau ekuilibrium lingkungan. Guattari menyebut ekosofi sebagai bidang baru dengan pendekatan monistik dan pluralistik. Guattari melalui titik optik ekosofi ini memandang ekologi sebagai suatu studi

\footnotetext{
I Menurut Sayyid Qutb bahwa pemahaman terhadap tauhid tidak boleh berhenti pada makna generiknya saja (dalam bingkai akidah), yaitu mengesakan Allah (wahdaniyat), melainkan harus berderivasi pada konsep kesatuan penciptaan (wahdat al-Khâliq al-Mudabbir), kesatuan kemanusiaan (wahdat al-insaniyat), kesatuan tuntunan hidup (wahdat nihayat al-hayat). Sayyid Qutb, Tafsîr Fî Zhilâl al-Qur'ân, Jilid VII, (Beirut: Ihyâ al-Turâts al-Arabi, 197I), 153.

12 Toshihiko Izutsu, Ethico-Religious Concepts in the Qur'an, (Montreal: McGill University Press, 1966), 119.
} 
tentang fenomena kompleks termasuk subyektifitas manusia, lingkungan dan relasi-relasi sosial, yang semuanya itu secara intim saling terkait. Gagasan Guattari tentang ekosofi menghubungkan tiga relasi harmonis antara pikiran manusia, masyarakat, dan lingkungan. ${ }^{13}$

Secara aplikatif ekosofi (akhlak berlingkungan) dapat terejahwantahkan dalam konsep ihsan. Menurut Nasr konsep ihsân ini merupakan jantung atau hati dari Islam, ${ }^{14}$ karena ihsân menimbulkan kesadaran bagi setiap manusia akan kehadiran Tuhan dalam setiap gerak dan langkahnya dalam menjalin relasi dengan alam dan makhluk lainnya. Sikap ihsan kepada lingkungan inilah yang akan melahirkan sikap yang ramah terhadapnya, bukan sebaliknya.

\section{Menuju Fikih Konservasi Berwawasan Antropokosmis}

Antropokosmis berarti pandangan yang menyatakan bahwa manusia adalah bagian organik dari alam. Pengertian ini meniadakan sikap manusia sebagai penakluk terhadap alam semesta. Term antropokosmisme sendiri dipopulerkan oleh Tu Wei Ming. Secara umum, pandangan ini merupakan kritik atas pandangan antroposentris yang menempatkan manusia sebagai pusat alam sehingga cenderung agresif terhadap lingkungan. Melalui perspektif antropokosmis, Ming ingin mengatakan bahwa konservasi lingkungan dapat dilakukan mulai dari perubahan cara pandang manusia yang antroposentris menuju antropokosmis. ${ }^{15}$ Perubahan ini memungkinkan konservasi lingkungan pesisirmemperoleh dukungan penuh dari tradisi kearifan tersebut. Oleh karena itu, fikih antropokosmis merupakan kritik dan antitesis terhadap fikih antroposentris.

\footnotetext{
13 Mudhofir Abdullah, Al-Quran dan Konservasi Lingkungan, (Jakarta: Dian Rakyat, 20 I0), 188.

14 Seyyed Hossein Nasr, The Heart of Islam; Enduring Values for Hummanity, (New York: Harper Sanfransisco, 2002), 314.

15 Tu Wei Ming, Centrality and Commonality: An Essay on Confucan Religiousness, (Albany: Suni Press, 1989), 5. Lihat juga, Tu Wei Ming, The Ecological Turn In New Confucian Humanism: Omplications for China and the World, 253; Tu Wei Ming, Ecological Implications of Confucian Humanism, 79.
} 
Antropokosmis dalam Islam merupakan etika lingkungan yang menitikberatkan pada paradigma relasi manusia dengan lingkungan secara holistik. Artinya, manusia selain merupakan bagian integral dari lingkungan ( $f i)$, tetapi ia juga menyadari dirinya memiliki potensi akal untuk memanfaatkan alam secara bertanggung jawab. Ideologi holistik-integralistik menawarkan satu sistem kehidupan berkesinambungan yang menjadi prasyarat terwujudnya kehidupan berkelanjutan. Paradigma holistikintegralistik ini menjanjikan kearifan lingkungan, yang layak untuk dikembangkan demi menggeser paradigma ektrim ekosentrisme atau inklusivisme, maupun paradigma antroposentrisme atau ekslusivisme. ${ }^{16}$

Fikih sebagai etika adalah sebuah cita-cita yang sebenarnya sudah pernah terwujud ketika fikih tidak dilihat secara dikotomis dari etika (moral). Etika lingkungan dalam Islam sebagai etika religius menggambarkan perilaku-perilaku yang seharusnya dilakukan atau ditinggalkan dalam hubungan manusia dan lingkungannya. Etika ini secara filosofis bersumber dari spirit moral yang digali dari teks-teks keagamaan, baik dari al-Qur'an maupun hadis. ${ }^{17}$ Dari sini, fikih antropokosmis berarti fikih lingkungan berdasarkan nilai spiritual religius Islam dan kemaslahatan ekologis secara holistik dan berkelanjutan.

Secara normatif, pengelolaan mangrove dalam perspektif ekosyariah merupakan kewajiban kolektif (fardh kifâyah). Kewajiban ini tidak sekadar dipahami apabila sejumlah pihak masyarakat telah melaksanakan kewajiban tersebut, seluruh anggota masyarakat lainnya tersebut sudah bebas dari tuntutan syariat. Karena kewajiban konservasi itu menjadi gugur disebabkan telah

\footnotetext{
${ }^{16}$ Fajar el-Dusuqy, "Ekologi al-Qur'an (Menggagas Ekoteologi Integralistik)", Jurnal Kaunia, Vol. IV, No. 2, (Oktober 2008), 182.

17 Diskursus etika dalam Islam memiliki empat aspek, yaitu: moralitas skriptural, teologis, filosofis dan relegius. Etika relegius adalah sistem nilai praktis yang bersumber dari spirit moralitas Islam yang bersumber dari al-Qur'an dan hadis. Majid Fakhri, Etika dalam Islam, terj. Zakiyuddin Baidhawi (Yogyakarta: Pustaka Pelajar, 1996), Xxi-xxiii; Suparman Syukur, Etika Religius, (Yogyakarta: Pustaka Pelajar, 2004), 196.
} 
terlaksananya suatu kewajiban yang dibebankan syariat sebagai bentuk kewajiban kolektif, fardh kifâyah. Sebaliknya, apabila seluruh anggota komunitas itu tidak ada seorang pun yang melaksanakannya, semuanya terkena dosa.

Paradigma tersebut, harus segera diubah karena terrealisasinya suatu fardh kifâyah secara maksimal ditentukan sejauh mana peran dan keterlibatan semua lapisan masyarakat Maka dari itu, semua anggota masyarakat harus mengambil peran dan turut andil dalam merealisasikan kewajiban kolektif tersebut secara gotong-royong. Dengan turut berpartisipasi dalam mengerjakan fardh kifâyah itulah, seorang mukallaf akan mengetahui secara pasti bahwa kewajiban kolektif telah benar-benar terselesaikan dengan baik dan maksimal. Sebelum mendapatkan kepastian atas terlaksananya suatu fardh kifâyah, setiap individu mukallaf harus memiliki kekhawatiran jika seandainya kewajiban bersama (kolektif) itu tidak terrealisasi dengan tuntas dan maksimal, sehingga seluruh anggota masyarakat, termasuk dirinya akan berdosa.

Di sisi lain, bagi yang terlibat merealisasikan fardh kifâyah tersebut, mereka boleh berbahagia karena akan memperoleh pahala dari dua sisi, yakni karena telah menunaikan kefardhuan dan membebaskan orang lain dari kewajibannya. Di sinilah, sebenarnya letak arti solidaritas atau kebersamaan dalam masyarakat muslim yang menjunjung tinggi nilai-nilai ukhuwah Islamiyah.

Dari sini, sejatinya, lompatan paradigma konsep fardh kifâyah sangat urgen digagas. Oleh karena itu, fardh kifâyah dalam konteks pelestarian lingkungan harus bersifat aktif, bukan pasif. Artinya, setiap individu harus memberikan sumbangsihnya dalam upaya pelestarian lingkungan pesisir secara kolektif sesuai dengan kapasitas masing-masing. Dengan demikian, pelestarian lingkungan pesisir akan terwujud secara maksimal dengan mengedepankan kebersamaan dan keberlanjutan sumberdaya wilayah pesisir. 
Berdasarkan uraian di atas, secara umum, menjaga lingkungan di wilayah pesisir menjadi kewajiban bagi masyarakat umum secara kolektif (fardh kifâyah). Akan tetapi yang perlu diperhatikan, bahwa hukum fardh kifâyah sebagai kewajiban kolektif yang diharapkan semua pihak berkontribusi secara bersama-sama telah menunaikan konservasi lingkungan laut dan pantai ini, akan berubah menjadi fardh 'ain sebagai kewajiban yang tidak bisa gugur kecuali setiap mukallaf di muka bumi ini telah menunaikannya, ketika dipastikan bahwa hanya ada pihak tertentu dari kelompok masyarakat tersebut yang mampu menunaikan kewajiban konservasi lingkungan tersebut. ${ }^{18}$ Oleh karena itu, peran dan kontribusi semua pihak dibutuhkan untuk saling bekerja sama dalam rangka mewujudkan program-program konservasi, baik keterlibatan masyarakat pesisir maupun pemerintah daerah sebagai pemangku kebijakan strategis dalam upaya penyelamatan lingkungan pesisir dari pencemaran, perusakan dan praktik penebangan hutan mangrove secara liar. Inilah pijakan produk figh al-bî'ah yang secara normatif mewajibkan menjaga lingkungan dan mengharamkan merusak lingkungan pesisir.

Untuk itu, dalam mewujudkan upaya konservasi lingkungan pesisir ini masyarakat harus saling bahu-membahu dalam merealisasikan program tersebut. Lebih jauh, keterlibatan dan peran aktif dari pemerintah menjadi suatu keniscayaan untuk memfasilitasinya. Dengan demikian, kerja sama antara masyarakat dan pihak pemangku kebijakan dalam hal ini adalah pihak pemerintah daerah harus bersinergi untuk menyelamatkan lingkungan pesisir dari kerusakan dan pencemaran lingkungan laut dan pantai.

${ }^{18}$ Berubahnya fardh kifâyah menjadi fardh 'ain disebabkan oleh dua hal. Pertama, ketika yang mampu melaksanakan perbuatan fardu kifayah hanya satu orang atau komunitas tertentu. Misalnya, jika ada orang tenggelam, dan hanya seorang yang mampu menyelamatkannya, maka ia hukumnya fardh 'ain untuk menyelamatkan orang yang tenggelam itu. Kedua, ketika perbuatan fardh kifâyah itu telah dikerjakan. Jika telah mengerjakan perbuatan yang fardh kifâyah, maka itu sama dengan fardh 'ain, artinya sama-sama harus diselesaikan. Wahbah al-Zuhaili, Ushûl al-Figh al-Islâmiy, Juz I, (Damaskus: Dar al-Fikr, 1986), 64. 


\section{Fiqh Mangrove: Formulasi Fikih Lingkungan Pesisir}

Fikih mangrove berarti konsep operasional fikih lingkungan yang dapat dijadikan sebagai panduan masyarakat muslim pesisir dalam rangka pelaksanaan ajaran Islam tentang pengelolaan hutan bakau di pesisir pantai. Pemahaman dan kesadaran secara normatifreligius terhadap kepedulian sumberdaya mangrove dan kehidupan tentunya akan memberikan dampak positif bagi keberlanjutan ekosistem dan kehidupan. Tentu, untuk menciptakan pemahaman dan kesadaran itu perlu peran semua pihak secara holistik-terpadu-sistemik sehingga proses pemanfaatan akan sebanding dengan upaya pelestarian.

\section{Anjuran Islam tentang Rehabilitasi Mangrove}

Ekosistem mangrove memiliki fungsi signifikan baik dilihat dari aspek atau nilai ekologis, lingkungan, maupun sosial ekonomi, di antaranya dapat mempertahankan kualitas air di kawasan pantai, melindungi pantai dengan mengurangi dampak dari badai, gelombang, dan banjir, berfungsi sebagai daerah pemijahan dan tempat makan berbagai jenis ikan (komersial dan lokal), merupakan tempat makan berbagai hewan-hewan laut baik yang bersifat bentik maupun pelagis serta berbagai jenis burung, dan dapat berfungsi sebagai sumber bahan atau produksi kayu. ${ }^{19}$

Terkait dengan rehabilitasi ini, Nabi saw sangat menganjurkan agar umat Muslim berperan aktif dalam kegiatan reboisasi atau penanaman kembali. Kegiatan ini, dimaksudkan untuk menciptakan keseimbangan dalam keberlanjutan kelestarian alam semesta, khususnya ekosistem di wilayah pesisir. Dalam hal ini, Nabi saw memberi motivasi khusus bahwa setiap orang yang menanam dan dengan tanamannya itu dapat memberikan manfaat kepada orang lain, maka tindakannya itu dianggap sebagai

\footnotetext{
19 Amran Saru, "Kontribusi Ekosistem Mangrove dalam Meningkatkan Potensi Sumber Daya Perikanan pesisir dan laut secara Berkelanjutan" dalam Andi lqbal Burhanuddin, dkk., Membangun Sumberdaya Kelautan Indonesia: Gagasan Pemikiran Guru Besar Universitas Hasanuddin, (Bogor: IPB Press, 2013), 64.
} 
sedekah. Nabi saw bersabda dalam hadis yang diriwayatkan alBukhari sebagai berikut: ${ }^{20}$

“Tidak ada seorang muslim yang menanam pohon atau menanam tanaman, lalu burung memakannya, atau manusia atau hewan, kecuali ia akan mendapatkan sedekah karena tanmannya." (HR. Bukhari). ${ }^{21}$

Hadis di atas, menunjukkan apresiasi yang tinggi terhadap upaya konservasi lingkungan melalui program penghijauan atau reboisasi mangrove. Aktivitas reboisasi tanaman (mangrove) merupakan perbuatan yang memiliki dimensi duniawi dan ukhrawi. Berdimensi duniawi, karena aktivitas tersebut dapat menyelamatkan krisis lingkungan dan berdimensi ukhrawi karena mengandung kesalehan yang bermuatan pahala. Oleh karena itu, menurut al-Qurtubi bahwa dalam upaya rehabilitasi lingkungan, bagi pemerintah (pemangku kebijakan rakyat) memiliki kewenangan untuk memerintahkan rakyatnya menanam pohon tertentu, termasuk juga tanaman mangrove. Al-Qurtubi berkata: "Bercocok tanam termasuk fardh kifâyah. Penguasa berkewajiban mendesak rakyatnya untuk bercocok tanam dan yang semakna dengan itu seperti menanam pohon." 22

Dalam konteks lingkungan pesisir pantai, anjuran ini dapat diimplementasikan dalam program konservasi hutan mangrove di sepanjang pesisir pantai. Hal ini sangat penting, mengingat tumbuhan mangrove sangat bermanfaat melindungi kawasan pesisir dari terjangan badai, angin topan atau bahkan tsunami. Karena tumbuhan mangrove termasuk ekosistem yang mampu menyerap air dalam jumlah yang besar sehingga mampu mencegah banjir. Akar dan dahan mangrove juga dapat menahan gelombang air pasang. Potensi hutan mangrove menurut penemuan mutakhir,

\footnotetext{
20 Muhammad Ibn Isma'il al-Bukhari, Shahîh al-Bukhâri, vol. III, (Mesir: Dar al-Fikr, t.t.), I35.

${ }^{2 !}$ Redaksi hadis lain, diriwayatkan oleh Muslim dari Jabir Ibn Abdullah r.a. ia berkata: Rasulullah saw bersabda: "Tidaklah seorang muslim menanam satu buah pohon kemudian dari pohon tersebut (buahnya) dimakan oleh binatang buas atau burung atau lainnya kecuali ia memperoleh pahala". (HR. Muslim).

22 Abu Abdillah Muhammad Ibn Ahmad al-Ansari al-Qurtubi, al-jâmi' li Ahkâm al-Qur'ân, (Beirut: Dar al-Fikr al-IImiyah, 1992), 300.
} 
tidak hanya berguna menghindari bencana bagi wilayah pesisir, tetapi dapat juga dijadikan cadangan pangan untuk membantu mencukupi kebutuhan masyarakat pesisir. ${ }^{23}$

Amran Saru menjelaskan fungsi dan manfaat mangrove dapat digeneralisasi menjadi empat hal penting, ${ }^{24}$ di antaranya: Pertama, secara fisik dapat melindungi lingkungan dari pengaruh oseanografi (pasang surut, arus, angin topan dan gelombang), mengendalikan abrasi dan mencegah intrusi air laut. Kedua, secara bio-ekologi dapat menjadi daerah asuhan (nursery ground), daerah mencari makan (feeding ground), dan daerah pemijahan (spawning ground) dari beberapa jenis ikan, udang serta dapat menyuplai unsur-unsur hara utama di pantai. Ketiga, secara ekonomi, dapat menjadi sumber kayu kelas satu, bubur kayu, bahan kertas, chips, arang dan ekowisata. Keempat, secara kimiawi, dapat mengakumulasi dan menetralisasi bahan pencemar yang larut dalam air maupun sedimen. ${ }^{25}$

Menimbang manfaat mangrove yang begitu signifikan, maka konservasi hutan mangrove menemukan urgensi dan relevansinya dengan penjelasan hadis di atas. Dengan demikian, sejak awal Islam hadir dengan ajaran yang ramah lingkungan, khsususnya

${ }^{23}$ Di Balikpapan misalnya, buah mangrove dimanfaatkan sebagai pengganti nasi. Caranya, dengan merebus buah mangrove sampai empuk kemudian dimakan dengan parutan kelapa. Untuk menghilangkan rasa pahit, buah mangrove tersebut ditaburi dengan nira dari pohon kelapa atau nipah yang banyak terdapat di sekitar pantai. Di Kabupaten Biak, masyarakat di sana menganggap buah mangrove yang populer disebut "buah aibon" yang artinya buah kayu sebagai komoditi agrobisnis andalan masa mendatang. http://www.kompasiana.com/hiero_8I/pemanfaatan-hutanmangrove-untuk-cadangan-pangan-masyarakat-pesisir_5528fda4fl7e6la I268b45f7 diakses pada Sabtu, 7 November 2015.

24 Amran Saru, "Kontribusi Ekosistem Mangrove dalam Meningkatkan Potensi Sumber Daya Perikanan Pesisir dan Laut secara Berkelanjutan" dalam Andi lqbal Burhanuddin, dkk., Membangun Sumberdaya Kelautan Indonesia: Gagasan Pemikiran Guru Besar Universitas Hasanuddin, (Bogor: IPB Press, 2013), 64.

25 Di era modern ini, mangrove tidak hanya bermanfaat sebagaimana dikemukakan di atas, tapi tumbuhan mangrove juga dapat menjadi obat-obatan. Kulit batang pohonnya dapat dipakai untuk bahan pengawet dan obat-obatan. Secara tradisional, dahulu tanaman ini digunakan sebagai obat penawar gigitan ular, rematik, gangguan alat percernaan dan lain-lain. Mangrove juga berfungsi sebagai bahan pengawet dan pewarna dalam produksi batik. Tanaman ini menghasilkan warna yang khas, yakni jingga-cokelat. Fungsi lain dari mangrove adalah sebagai bahan bangunan. Koran FAJAR, Edisi Selasa, 27 Januari 2015, 19. 
memberikan perhatian khusus terhadap program penghijauan dan mengapresiasi aksi-aksi peduli terhadap lingkungan demi terciptanya keseimbangan alam semesta. Perintah menanam tumbuhan mangrove diikuti pula dengan larangan penebangannya yang menyebabkan hilangnya manfaat mangrove itu atau munculnya kerusakan lingkungan. Abu Dawud meriwayatkan hadis yang menunjukkan bahwa perusak atau penebang tanaman akan mendapat siksaan yang pedih di neraka. Nabi saw bersabda:

“Telah menceritakan kepada kami Nasr ibn Ali, telah mengabarkan kepada kami Abu Usamah dari Ibnu Juraij dari Usman ibn Abu Sulaiman dari Sa'id ibn Muhammad ibn Jubair ibn Mut'im dari Abdullah ibn Habsyi ia berkata, "Rasulullah saw bersabda: “Barang siapa menebang pohon bidara maka Allah akan membenamkan kepalanya dalam api neraka." Abu Dawud pernah ditanya tentang hadis tersebut, lalu ia menjawab, "secara ringkas, makna hadis ini adalah bahwa barang siapa menebang pohon bidara di padang bidara dengan sia-sia dan zalim, padahal itu adalah tempat berteduh para musafir dan hewan-hewan ternak, maka Allah akan membenamkan kepalanya di neraka." (HR. Abu Dawud). ${ }^{26}$

Berdasarkan hadis tersebut, jelas bahwa Nabi saw sangat menganjurkan program konservasi mangrove sebagai upaya untuk melindungi pesisir pantai dari terjadinya abrasi dan perlindungan bagi masyarakat pesisir secara umum dari terjangan ombak pasang atau bahkan terjangan tsunami. Di pihak yang lain, Islam juga dengan jelas melarang tindakan destruktif manusia untuk menebang tumbuhan mangrove yang secara illegal dan tidak bertanggung jawab.

Oleh karena itu, rehabilitasi mangrove harus dilakukan secara berkelanjutan dan terprogram. Inventarisasi lahan pada jalur hijau yang memenuhi persyaratan tumbuh bagi tanaman mangrove perlu dilakukan secara luas. Kawasan jalur hijau yang cocok untuk pengembangan mangrove terdiri dari lahan kosong, lahan tambak, dan areal hutang mangrove yang ada sekarang. Yang tidak

${ }^{26}$ Sulaiman bin al-Asy'as Abu Dawud al-Sijistani, Sunan Abi Dawud, No. Hadis 5239, jilid 4, (Beirut: Maktabah al-Asriyah, t.t.), 36I. 
memenuhi persyaratan teknis adalah lahan yang tandus, berbatu karang, atau ada bangunan fisik (seperti dermaga atau pemukiman). ${ }^{27}$

\section{Alih Fungsi Mangrove Berdasarkan Analisis Maslahat/ Manfaat}

Kawasan mangrove menjadi gundul disebabkan oleh ulah para pemodal yang melakukan konversi lahan, baik untuk kepentingan industri, properti ataupun bisnis pariwisata. Ironisnya, terkadang tindakan tersebut justru dibiarkan oleh pemangku kebijakan dalam hal ini pemerintah daerah setempat karena dianggap bisa menambah pemasukan bagi pihak-pihak yang memegang otoritas atau menaikan angka Pendapatan Asli Daerah (PAD).

Paling tidak ada dua faktor penting yang berkaitan dengan kerusakan ekosistem mangrove di kawasan pesisir. Faktor yang pertama adalah pesatnya pembangunan industri di pesisir pantai. Pertumbuhan industri di wilayah pesisir ditengarahi sebagai pihak yang paling besar berkontribusi dalam pencemaran lingkungan kelautan. Untuk satu dekade terakhir ini kondisi lingkungan laut di kawasan pantai sangat terasa sekali dampak kerusakannya karena berpengaruh langsung terhadap penurunan hasil tangkapan para nelayan, utamanya yang masih mengandalkan alat tangkap tradisional. Perkembangan industri-manufaktur memang diakui telah mampu menjawab persoalan kesejahteraan dan kesenjangan sosial, tetapi akibatnya ternyata harus dibayar sangat mahal karena berdampak negatif terhadap kelestarian lingkungan. Akselerasi pertumbuhan industri di kawasan daratan dan pesisir telah mengakibatkan gundulnya hutan mangrove di sekitarnya.

Faktor kedua yang juga merisaukan bagi usaha menjaga kelestarian ekosistem mangrove di kawasan pesisir yaitu meningkatnya populasi penduduk yang semakin pesat. Secara otomatis, dengan bertambahnya jumlah penduduk di kawasan

${ }^{27}$ Rahardjo Adisasmita, Pembangunan Kelautan dan Kewilayahan, (Yogyakarta: Penerbit Graha IImu, 2006), 55

\begin{tabular}{l|l}
122 & $\begin{array}{l}\text { al-Daulah } \\
\text { Vol. 7. No. 1. April } 2017\end{array}$
\end{tabular} 
pesisir pantai menuntut ketersediaan lahan yang cukup untuk kebutuhan "papan" dan aktivitas bisnis penunjang. Untuk memenuhi kebutuhan tempat pemukiman tersebut dibuatlah kebijakan tentang konversi lahan. Pengadaan proyek konversi atau alih fungsi lahan berdampak pada dilakukannya penebangan pohon-pohon mangrove demi memenuhi kecukupan lahan.

Penebangan tumbuhan mangrove sebenarnya bukan mutlak terlarang, tetapi dapat dibolehkan sepanjang mengandung manfaat. ${ }^{28}$ Sebaliknya, jika alih fungsi lahan tersebut mengandung mafsadat (yang tidak bertanggung jawab dan melanggar prosedur) maka hukumnya diharamkan. Analisis manfaat inilah yang menjadi penentu kebijakan dalam konversi lahan dari hutan mangrove menjadi pemukiman, tambak atau kawasan industri dan lainnya. Dalam hal ini berlaku kaidah dar' al-mafâsid muqaddam 'alâ jalb al-mashâlih. ${ }^{29}$ Dalam konteks fikih antropokosmis, mendahulukan untuk menghindarkan kerusakan dan dampak negatif yang ditimbulkan daripada mengutamakan untuk mendapatkan kemaslahatan dan nilai ekonomis semata tanpa memerhatikan kemaslahatan ekologis. Jika terpaksa mangrove itu harus ditebang, maka harus dilakukan rehabilitasi dan reboisasi mangrove agar ekosistemnya tetap terpelihara dan terlestarikan.

\section{Green-Constitution: Regulasi Pengelolaan Mangrove}

Persoalan lingkungan merupakan persoalan kebijakan. Oleh karenanya, persoalan lingkungan termasuk persoalan konstitusi atau yang sering disebut dengan green constitution (konstitusi hijau)..$^{30}$ Arah kebijakan hukum di bidang lingkungan hidup disebut

${ }^{28}$ Imam Ahmad meriwayatkan hadis yang menunjukkan bahwa pohon yang mengganggu para pengguna jalan kemudian ditebang, maka penebang pohon tersebut justru dimasukkan ke dalam

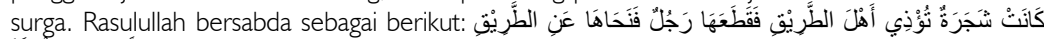
فihat, Ahmad Ibn Hanbal, Musnad Ahmad ibn Hanbal, vol. 2, 304.

${ }^{29}$ Kaidah ini salah satu kaidah pentarjihan antara maslahat dan mafsadat. Secara umum, kaidah ini mengisyaratkan bahwa bila ada manfaat dan mafsadat secara bersamaan, maka diutamakan untuk mendahulukan untuk menghindarkan dari mafsadat daripada mendapatkan maslahat. Lihat, Fatwa Majelis Ulama Indonesia Nomor 22 Tahun 201 I tentang Pertambangan Ramah Lingkungan, 6

30 Term "green constitution"ini, di Indonesia dipopulerkan oleh Jimly Asshiddiqqie. Menurutnya, salah satu aspek yang menjadi gagasan materi muatan konstitusi adalah kebijakan hukum pengelolaan 
politik hukum lingkungan. Politik hukum lingkungan merupakan arah kebijakan hukum yang ditetapkan oleh pemerintah untuk mencapai tujuan dan sasaran dari perlindungan dan pengelolaan lingkungan hidup. ${ }^{31}$

Upaya pengelolaan mangrove tidak akan berjalan secara maksimal tanpa didukung kebijakan politik yang bernuansa ekologis yang berpihak kepada keberlanjutan ekosistem mangrove. Oleh karena itu, kebijakan-kebijakan yang anti-ekologi, mekanistik, dan materialistik harus diarahkan menuju kebijakan politik yang sadar lingkungan (eco-politic). Kebijakan politik ini harus diwujudkan melalui penerbitan regulasi (Perda) yang baik dari pemangku kebijakan yang dalam hal ini pemerintah daerah tentang pengelolaan mangrove secara berkelanjutan.

Kebijakan yang berkenaan dengan pengelolaan mangrove di kawasan pesisir di antaranya dengan penetapan kebijakan green belt (jalur hijau). Jalur hijau adalah zona perlindungan mangrove yang dipertahankan di sepanjang pantai dan tidak diperbolehkan untuk ditebang, dikonversikan atau dirusak. Pada peranan kebijakan ini pemerintah seharusnya menerapkan kebijakan green belt dengan didukung adanya peraturan daerah yang mengatur perlindungan mangrove, sehingga dalam pelaksanaan kebijakan pemerintah tidak hanya menghimbau kepada pengusaha mengenai adanya green belt, tetapi lebih dari itu dapat memberikan sanksi bagi perusak vegetasi mangrove di pesisir patai.

Oleh sebab itu, kebijakan pengelolaan hutan mangrove harus dilaksanakan secara terpadu dengan memperhatikan fungsi daerah asuhan bagi sumber daya ikan, tata ruang, keterlibatan masyarakat dengan tetap melindungi keragaman jenis mangrove, menghindari

lingkungan. Konstitusi yang memuat kebijakan hukum pengelolaan lingkungan inilah yang disebut dengan "konstitusi hijau" atau "green constitution". Semakin lengkapnya hal-hal mendasar mengenai norma pengelolaan lingkungan dimuat dalam konstitusi, maka semakin "hijau"-lah suatu konstitusi, begitu juga sebaliknya. Jimly Assiddiqqie, Green Constitution, Nuansa Hijau Undang-Undang Dasar Republik Indonesia Tahun 1945, (Jakarta: Raja Grafindo Persada, 2009), 4,; Muhammad Akib, Politik Hukum Lingkungan, (Jakarta: Rajawali Press, 2013), 14.

${ }^{31}$ Eko Nurmardiansyah, "Eco-Philosophy dan Implikasinya dalam Politik Hukum Lingkungan di Indonesia", Jurnal Melintas, edisi Januari, 20।4, 95. 
percepatan penurunan ketersediaan hutan mangrove dan melarang penebangan pada kawasan lindung. ${ }^{32}$ Dengan demikian, diharapkan pengelolaan mangrove berwawasan ekologis ini dapat melindungi ekosistem pantai dan memelihara kelestariannya.

\section{Penutup}

Dari uraian sebelumnya dapat disimpulkan bahwa pengelolaan mangrove sebagai kekayaan sumberdaya di wilayah pesisir dapat dilakukan dengan pendekatan eko-syariah. Sebagai suatu pendekatan yang termanifestasi dalam konsep ekoteologi dan ekosofi, eko-syariah dapat melahirkan kesadaran baru tentang keterlibatan secara intens dalam pelestarian dan rehabilitasi habitat mangrove di lingkungan pesisir.

Nilai-nilai religius yang berwawasan antropokosmis dapat melahirkan konstruksi fikih mangrove yang menjadi panduan bagi masyarat pesisir. Konstruksi fikih mangrove dapat digali dari pemahaman secara mendalam terkait hal berikut: pertama, teks-teks keagamaan yang menganjurkan untuk merehabilitasi habitat mangrove; kedua, prosedur alih fungsi lahan mangrove berdasarkan pertimbangan asas manfaat-mafsadat; ketiga, keniscayaan pemerintah daerah menerbitkan regulasi untuk mengatur pengelolaan mangrove secara berkelanjutan.

\section{Daftar Pustaka}

Abdillah, Mujiyono. Fikih Lingkungan. Yogyakarta: Unit Penerbitan dan Percetakan YKPN, 2005.

\footnotetext{
32 Kusmana menjelaskan bahwa pengelolaan mangrove harus dapat dipanen secara berkelanjutan dan dipertahankan secara alami seperti semula. Preservasi sebagian areal mangrove yang betulbetul tidak terganggu (pristine mangrove forest) seharusnya diperjuangkan atau dialokasikan sehingga jika suatu pengelolaan mengalami kegagalan yang menyebabkan kerusakan bahkan hilangnya mangrove tersebut, bagian pristine mangrove forest dapat menjadi penyelamat kondisi tersebut. Ekosistem mangrove harus dikelola berdasarkan pada paradigma ekologi yang meliputi prinsipprinsip interdependensi antar unsur ekosistem, sifat siklus dari proses ekologis, fleksibilitas, diversitas dan koevolusi dari organisme beserta lingkungannya dalam suatu unit fisik DAS. Lihat, Kusmana C. Konsep Pengelolaan Mangrove Yang Rasional, diunduh tanggal 7 November 2015 tersedia pada http://cecep_kusmana.staff.ipb.ac.id/files/20 I I/0 I/20 I 0-Paper-Konsep-Pengelolaan-Mangrove-

Yang-Rasional.pdf.
} 
Adisasmita, Rahardjo. Pembangunan Kelautan dan Kewilayahan, Edisi Pertama. Yogyakarta: Penerbit Graha Ilmu, 2006.

Akib, Muhammad. Politik Hukum Lingkungan. Jakarta: Rajawali Press, 2013.

Assiddiqqie, Jimly. Green Constitution, Nuansa Hijau Undang-Undang Dasar Republik Indonesia Tahun 1945. Jakarta: Raja Grafindo Persada, 2009.

Badan Pusat Statistik. Statistik Lingkungan Hidup Indonesia 2014. Jakarta: Sub Direktorat Statistik Lingkungan Hidup, t.t.

Bukhari (Al-), Muhammad Ibn Isma'il. Shahîh al-Bukhari, vol. III. Mesir: Dar al-Fikr, t.th.

Burhanuddin, Andi Iqbal dkk. Membangun Sumberdaya Kelautan Indonesia: Gagasan Pemikiran Guru Besar Universitas Hasanuddin. Bogor: IPB Press, 2013.

Dusuqy (el-), Fajar. “Ekologi al-Qur'an (Menggagas Ekoteologi Integralistik)". Jurnal Kaunia. Vol. IV, No. 2, Oktober 2008.

Izutsu, Toshihiko. Ethico-Religious Concepts in the Qur'an. Montreal: McGill University Press, 1966.

Khalid, Fazlun. "Islam and Environment", in Timmerman P. (ed) Encyclopedia of Global Environment Change. Chichester: John Wiley \& Sons Ltd, 2002.

Ming, Tu Wei. Centrality and Commonality: An Essay on Confucan Religiousness. Albany: Suni Press, 1989.

Mutahhari, Murtadha. Fundamentals of Islamic Thought. Berkeley: Mizan Press, 1985.

Nasr, Sayyed Hossein. The Heart of Islam; Enduring Values for Hummanity. New York: Harper Sanfransisco, 2002. . The Heart of Islam; Enduring Values for Hummanity. New York: Harper Sanfransisco, 2002.

Nurmardiansyah, Eko. "Eco-Philosophy dan Implikasinya dalam Politik Hukum Lingkungan di Indonesia". Jurnal Melintas, edisi Januari, 2014.

Qurtubi (Al-), Abu Abdillah Muhammad Ibn Ahmad al-Ansari. Jâmi' li Ahkâm al-Qur'ân. Beirut: Dar al-Fikr al-Ilmiyah, 1992. 
Qutb, Sayyid. Tafsîr Fî Zhilâl al-Qur'ân, Jilid VII. Beirut: Ihya al-Turas al-Arabi, 1971.

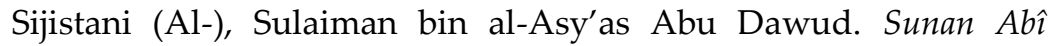
Dâwud, No. Hadis 5239, Jilid 4. Beirut: Maktabah al-Asriyah, t.t.

Sukarni. Fikih Lingkungan Hidup. Banjarmasin: Antasari Press, 2011. Syukur, Suparman. Etika Religius. Yogyakarta: Pustaka Pelajar, 2004. Tohopi, Ridwan. Konservasi Pesisir dalam Perspektif Studi Islam. Cet. I; Yogyakarta: Pustaka Pelajar, 2014.

Yazdi, Muhammad Taqi Misbah. At-Tauhid or Monotheism, As in The Ideological and The Value System of Islam. Iran: Islamic Propagation Organization, t.th.

Zuhaili (Al-), Wahbah. Ushûl al-Fiqh al-Islâmi, Juz I. Cet. I; Damaskus: Dar al-Fikr, 1986. 